\title{
Relationship between Selected Personal Determinants and Examination Cheating among Kenyan Secondary School Students
}

\author{
John Timon Odhiambo Owenga
}

\author{
PhD.Jaramogi Oginga Odinga \\ University of Science \& Technology,
}

\author{
Peter J. O. Aloka \\ Department of Psychology \& Educational Foundations, \\ Jaramogi Oginga Odinga University of Science \& Technology \\ Pamela A. Raburu \\ Department of Psychology \& Educational Foundations, \\ Jaramogi Oginga Odinga University of Science \& Technology
}

Doi: 10.2478/ajis-2018-0007

\begin{abstract}
The present study investigated the relationship between selected personal determinants and examination cheating among Kenyan secondary school students. This study used a Sequential Explanatory design. The target population was 51,900 students in Kisumu County within 153 public secondary schools categorized as 2 National secondary schools, 21 extra county schools, and 130 county and sub-county schools. A simple random sampling technique was used to determine sample size which comprised of 380 respondents since the study was confined within specific ecological boundary which was public secondary schools. Data collection instruments included questionnaires, for general data collection from the respondents and in-depth interview schedules for one to one interview of respondents. The finding of the study shows that there was statistically significant positive correlation $(r=.592, n=360, p<.05)$ between Personal determinants and overall perceived level of exams cheating. It is evident from the model that student personal characteristics accounted for $35.1 \%$, as signified by coefficient $R^{2}=.351$, of the variation in perceived level of examinations cheating among students in secondary schools. it is evident that gender made the highest (Beta=.467) contribution as personal determinant on explaining the dependent variable, when the variance explained by all other variables in the model was controlled for. Student self-esteem had the least effect (Beta=.048) on examinations cheating. However, all the personal determinants had statistically significant influence on examinations cheating among the secondary schools students. The calculated effect size (eta squared=.3514) indicate that there was quite a substantial amount of variance in level of examinations cheating caused by variability in the personal determinants of the students. This suggests that $35.1 \%$ of the variance in the perceived exams cheating was accounted for by the personal determinants of the secondary school students, when other variables were controlled. Teacher counselors to assess and identify those students at risk and change their perception on examination cheating due to low self-efficacy.
\end{abstract}

Keywords: Personal determinants; examination cheating; Kenyan; secondary school students; self-esteem; self-efficacy; locus of control; gender 


\section{Introduction}

Examination cheating is not only a problem in Kenya but also a worldwide phenomenon. According to Cizek (2003), cheating in examination can be defined as "fraud, dishonesty or deceit in academic assignment or using, or attempting to use, or assisting in academic assignment or using, or attempting to use, or assisting others in using materials that are inappropriate or prohibited in context of the academic assignment in question. According to Barkely (2009) study in USA, students always prefer shortcut in achieving their grades and maintaining their sense of personal integrity or otherwise, rather than investing their time and effort on serious academic work and this prevalence of academic dishonesty has gravening effects at personal, school, home or community levels. Examination cheating according to McCabe and Pavella (2006) in USA is due to academic integrity in examination handling which is so much compromised that something ought to be done. Examination malpractice is a deliberate move which is well planned and organized by the parents, peers and executed by the students (Candidates) according to Kisamore, Stone, and Jahawar (2009).

Cheating means: deprived of some things valuable by use of deceit or fraud such as cheating in school assignment, writing on palms as indicators of low self-efficacy, (Christine, Graven, Gary \& Rydall, 2015). Thorough adherence to the examination rules is enough to raise the learners selfefficacy and hence to stamp out the act of examination cheating (Anderman \& Murdock, 2007). However, the most preferred deterrents to discourage cheating in classrooms were: - the use of different forms of tests by teachers, giving information to students by teachers why they should not cheat and thorough invigilation and watching of students as they take exams and also that moral development is a long term strategy to stamping out examination cheating and recommended that students need to be developed morally in order to avoid cheating (Davis, Drinan \& Gallant ,2012, Happed \&Jennings,2008).

Parents look for short cut for their children by giving them synthesized notes and impersonation support given that most of the impersonations are propagated by the parents or home factors where one may use his or her siblings to impersonate them, (Fasasi, 2008) while in a separate study in USA, Kisamore, Stone and Jahawar (2009) emphasized that cheating is normally allowed by the parents and also supported the idea of parents pressurizing their children to do well thus there are parents who even encourage their children to copy the work of the brighter pupils in order to pass a test or examinations. The study further showed that methods or ways involved in exam cheating may be so many but the fact remains that whether it is one or more it's unacceptable to use ulterior methods to do or pass examination. Bandura (1986) asserted that low self efficacy among students is one of the main factors determining examination cheating in schools. Adeyemi (2010) confirmed that interaction with peers who have inclination to examination cheating can also lead to examination malpractice.

The study was guided by the Theory of Planned Behaviour. The theory of Planned Behaviour is a theory about the link between beliefs and behaviour which was proposed by Ajzen, (1991) to improve on the predictive power of the theory of reasoned action by including perceived behavioural control, relations among beliefs, attitudes, behavioral intentions and behaviours in various fields. (Ajzen, 1991 \& Stone, 2009). Theory of reasoned action was an invention by Fishbein and Ajzen in (1975), which explains that there is a high correlation of attitudes and subjective norms to behavioural intention and subsequently to behaviour (Ajzen, \& Fishbein, 2005). This theory also states that expectations such as motivation, performance, feelings, and behavioral reactions are always not spontaneous but planned.

Literature on personal determinants of examination cheating exists. For example, In USA, Beauchamp, and Murdock, (2009) revealed that $78 \%$ of the students admitted to have cheated or assisted someone to cheat in tests or examinations. Gideon (2007) revealed that the two traits that combine and account for a statistically and practically significant proportion of variance in academic cheating were lack of effort and need for high excitement seeking. McCabe, Trevino and Butterfield (2012) revealed that students cheat mainly because of peer influence, or rather because others do it. Majority of the respondents concurred that they cheat because of the influence of friends and some because of lack of self-efficacy. In USA by Davis, Drian, and Gallant, (2012) revealed that 
high school students with high intelligence cheated less than students with lower intelligence on I.Q tests. In another study by Christopher, (2012) at Minnesota State University Mankato revealed that high specific self - efficacy in individuals is less likely cheat while both levels - general self-efficacy (G.S.E) and specific self-efficacy (SSE) predict lower rates of cheating overall. The study further revealed that general self efficacy positively correlates with cheating while specific self efficacy does not predict cheating. Chudzika and Zupala (2014) in a survey carried out in Poland, where a sample of 285 students were sampled using purposive sampling technique revealed that; the locus of central justice sensitivity, and some individual ethical philosophical dimensions are significant predictors for accepting dishonest behaviour in examinations.

A study carried out by Grimes and Razek (2006), in Belarus; Croatia, Kyrgyzstan, Lithuania, Russia, Ukraine and USA on determinants of cheating by high school students revealed that Significant determinants were personal beliefs about ethics and social acceptability of cheating and various attributes of classroom, environment. Scanica (2016) revealed that one of the determinants of examination cheating among students is the writing strategies that are so obscure which they pass to one another. The students capitalize on the lack of strict invigilators and supervisors of the examinations. Low efficacious students always find it challenging to tackle examinations within the time limit and so they resort to depend on the more efficacious colleagues who help them to cheat, (Scanica, 2016). A study carried out by Bayindira, Ozel and Bakir, (2013) in Kutaya, Turkey indicated that the major determinant of examination cheating among students is lack of confidence in their memory, level and low self-efficacy. Kisamore, Stone and Jahawar, (2007), found out that there is a relationship between individual situational factors and misconduct such as examination malpractice or poor academic integrity. Ugodulunwa, (2011) further confirmed that attitude of students in examination cheating is significant in levels of study which include:-Interaction, effect of gender and religion, course of study. The study observed that the way students interact with their peers determines their attitude towards learning and also behaviour during examinations which may lead to cheating in examination and so Behavioural and attitudinal factors among students determine students' participation in cheating in examination. A study was carried out by Afokasade, Airate, Suleiman (2014) in Lagos state, Nigeria revealed that the main reason that made the students to cheat was lack of confidence. Ong'ong'a and Akaranga (2013) study clarified that students involvement in examination malpractices was mainly due to personal motivation which is self-efficacy and these personal factors are due to inadequate preparation and the desire to pass at all costs.

In Kenya, there is evidence of cheating as indicated by the number of examination results canceled by KNEC. It is evident that each year has cases of exam cancelation. It can be noted from the table that the peaks of exam cheating cases are in the year 2011, 2013, and 2015 while the rest of the years $(2012,2014$, and 2016) have been registering reduction in number of examination cheating cases. This is an indicator that some attempts are made to try to eliminate the vice of examination cheating but the culprits always try to invent new cheating tactics every time they are discovered. The present study investigated the relationship between selected personal determinants and examination cheating among Kenyan secondary school students.

\section{Research Methodology}

This study used a Sequential Explanatory design in Mixed Methods approach whose characteristics is collection and analysis of quantitative data followed by collection and analysis of qualitative data (Onueghbuzie \& Mayo 2013). Its purpose is to use qualitative data to help explain the results or findings by quantitative data. It explores, explains and interprets the phenomenon under study using both quantitative and qualitative information. The target population was 51,900 students in Kisumu County within 153 public secondary schools categorized as 2 National secondary schools, 21 extra county schools, and 130 county and sub-county schools with a total student population of 51,900 in Kisumu County (MOEST 2014). A simple random sampling technique was used to determine sample size which comprised of 380 respondents since the study was confined within specific ecological boundary which was public secondary schools. Data collection instruments included questionnaires, for general data collection from the respondents and in-depth interview 
schedules for one to one interview of respondents. To ensure that data collection instrument is valid, the instruments were pre-tested in one of the selected schools using a reasonable number of respondents. Experts from Department of Psychology and Educational Foundations of Jaramogi Oginga Odinga University of Science and Technology were consulted about the content validity of instrument, ambiguity of question items and their relevancy. To ascertain the reliability of the instruments, a pretest (pilot) study was carried out in one of the schools within the county which was not part of the study. Quantitative data was analyzed by descriptive statistics and inferential statistics. In addition, Creswell (2014) highlights the analysis steps in qualitative analysis to include; Preliminary exploration of data by reading through it several times, coding data by segmenting and labeling of text, using codes to develop themes by aggregating similar codes together and connecting the interrelated themes.

\section{Findings and Discussion}

To investigate whether there was any statistical relationship between school determinants and exams cheating, the null hypothesis was tested. To do this, a Pearson Product Moment Correlation Coefficient was computed, with overall scores from the two school determinants (Self-efficacy, Selfesteem, Locus of control and gender) put together as the independent variables, while the level of exams cheating as the dependent variable. The p-value was set at .05, the null hypothesis was rejected when the p-value was less than .05 but it was accepted when the p-value obtained was greater than .05. Preliminary analyses were performed to ensure no violation of the assumptions of normality. Table 1 shows the correlation analysis results in SPSS output.

Table 1: Correlations between Exams Cheating and School Determinants

\begin{tabular}{llcc}
\hline & & Exams Cheating & Personal Determinants \\
\hline Exams Cheating & Pearson Correlation & 1 & .592 \\
& Sig. (2-tailed) & & .000 \\
& $\mathrm{~N}$ & 360 & 360 \\
School Determinants & Pearson Correlation & $.592^{* *}$ & 1 \\
& Sig. (2-tailed) & .000 & 360 \\
& $\mathrm{~N}$ & 360 & 360 \\
\hline
\end{tabular}

**. Correlation is significant at the 0.01 level (2-tailed).

The finding of the study shows that there was statistically significant positive correlation ( $r=.592$, $\mathrm{n}=360, \mathrm{p}<.05$ ) between Personal determinants and overall perceived level of exams cheating. Given that the relationship was statistically significant, the hypothesis that, "there is no statistical significant relationship between Personal determinants and exams cheating" was rejected. It was therefore concluded that examinations cheating significantly correlated to Personal determinants. However, to estimate the level of influence of Personal determinants on examinations cheating, a multiple regression analysis was also used to test the null hypothesis that, "there is no statistical significant relationship between personal determinants and examinations cheating among secondary school students in Kisumu County". The hypothesis was tested by setting the p-value at .05 , where the null hypothesis was rejected when the p-value was less than .05 but it was accepted when the $p$-value obtained was greater than .05 .

The predicators used here were; self-efficacy, self-esteem, locus of control, and gender. However, given that the predicator (locus of control and gender) were in categorical scale; additional steps had to be followed to allow use of multiple regression analysis and also to ensure that the results are interpretable, as used by McCulloch \& Searle (2000) and Benoit (2010). These steps involved recording the categorical variable into a number of separate, dichotomous variables in a process referred as the "dummy coding," as explained in the: htt://www.psychstat.missouristate.edu/multibook/mlt08m.html. First, a coefficient of determination was computed to estimate the level of influence of personal determinant on examinations cheating. This was done using of regression analysis and the result was as shown in Table 2. 
Table 2: Model Summary on Regression Analysis of Influence Personal Determinants and Exams Cheating

\begin{tabular}{cccccc}
\hline Model & R & R Square & Adjusted R Square & Std. Error of the Estimate & Durbin-Watson \\
\hline 1 & $.592^{\mathrm{a}}$ & .351 & .343 & .44779 & 1.709 \\
\hline
\end{tabular}

a. Predictors: (Constant), Gender Influence, Self-efficacy, Locus of Control, Self-esteem

b. Dependent Variable: Exams Cheating

It is evident from the model that student personal characteristics accounted for $35.1 \%$, as signified by coefficient $R^{2}=.351$, of the variation in perceived level of examinations cheating among students in secondary schools. However, Analysis of Variance (ANOVA) was computed as shown in Table 3 to determine whether personal determinants were a true significant predictor of exams cheating and also test hypothesis.

Table 3: ANOVA Results: Influence of Personal Determinants

\begin{tabular}{ccccccc}
\hline & Model & Sum of Squares & Df & Mean Square & F & Sig. \\
\hline & Regression & 38.447 & 4 & 9.612 & 47.935 & $.000^{b}$ \\
Residual & 71.183 & 355 & .201 & & \\
& Total & 109.630 & 359 & & & \\
\hline
\end{tabular}

a. Dependent Variable: Exams Cheating

b. Predictors: (Constant), Locus of Control, Self-esteem, Self-efficacy, Gender Influence

From the ANOVA Table 3 , it is evident that the p-value for the F statistic is $<.05$, meaning that at least one of the variables of personal determinants was a significant predictor of exams cheating, $[F(4,355)=47.935, p<.05]$. Given that a statistical significance was established, there was adequate evidence to reject the null hypothesis that, "there is no statistical significant influence of personal determinants on examinations cheating among students in secondary schools in Kisumu County". Hence, the alternative hypothesis was accepted and conclusion reached that there is a significant influence of personal determinants on exams cheating among students in secondary schools in Kisumu County. This finding agrees with results in the previous sub-sections of this objective that had shown that all personal determinants had statistical significant influence on exams cheating. In addition coefficients values were computed to investigate the influence of each aspect of personal determinants, as in Table 4.

Table 4: Coefficients Output on Personal Determinants

\begin{tabular}{|c|c|c|c|c|c|c|c|}
\hline \multirow{2}{*}{ Model } & \multicolumn{2}{|c|}{ Unstandardized Coefficients } & \multirow{2}{*}{\begin{tabular}{|c} 
Standardized Coefficients \\
Beta
\end{tabular}} & \multirow{2}{*}{$\mathrm{T}$} & \multirow{2}{*}{ Sig. } & \multicolumn{2}{|c|}{ Collinearity Statistics } \\
\hline & $B$ & Std. Error & & & & Tolerance & VIF \\
\hline (Constant) & 1.475 & .327 & & 4.510 & .000 & & \\
\hline Self-efficacy & -.157 & .047 & -.165 & -3.317 & .001 & .742 & 1.348 \\
\hline 1Self-esteem & -.048 & .061 & -.048 & -2.784 & .033 & .498 & 2.007 \\
\hline Locus of Control & .092 & .043 & .122 & 2.131 & .034 & .562 & 1.778 \\
\hline Gender Influence & .467 & .077 & .443 & 6.067 & .000 & .343 & 2.919 \\
\hline
\end{tabular}

a. Dependent Variable: Exams Cheating

From Table 4, it is evident that gender made the highest (Beta=.467) contribution as personal determinant on explaining the dependent variable, when the variance explained by all other variables in the model was controlled for. Student self-esteem had the least effect (Beta=.048) on examinations cheating. However, all the personal determinants had statistically significant influence on examinations cheating among the secondary schools students. The calculated effect size (eta squared=.3514) indicate that there was quite a substantial amount of variance in level of examinations cheating caused by variability in the personal determinants of the students. This 
suggests that $35.1 \%$ of the variance in the perceived exams cheating was accounted for by the personal determinants of the secondary school students, when other variables were controlled.

Self-efficacy was also observed as theme during the in-depth interview, since most of the respondents gave credence to it. It emerged from the analysis that several students cheat due to low self-efficacy. Their expressions were found to be related to self-efficacy and accounted for the largest number of responses. It was established that teachers' influence and syllabus coverage accounted for several responses which was slightly higher than technology, exam management and parental influence which were also significantly observed by the respondents. The expressions of the respondents were transcribed and were found to be significant in showing that exam cheating also has personal determinants. The responses or expressions by the various respondents gave indications that self efficacy is a personal determinant to examination cheating given that most of respondents gave expressions:

Most of students in school lack self confidence when it comes to examination; they instead prefer cheating to examination integrity. (Head teacher. 2)

Cheating in exams is caused by lack of trust on self. The students who cheat always feel that they can't make it on their own. They even don't trust the ability of their teachers and they feel that their school is substandard in teaching. (Parent. 1)

Examination cheating is mainly among students who don't work hard in school and therefore are not advantaged when it comes to tackling challenging or difficult problems. (Teacher. 4)

The expressions from Head teacher 2, Parent 1 and Teacher 4 denote how self-efficacy as a determinant to examination cheating in schools, is a key factor to be considered. The respondents from the study indicate that self efficacy is not only a personal determinant but also a school determinant. They observed that students who lack confidence in themselves, on their teacher and in their schools are always prone to fall prey to exams irregularities or cheating. Self efficacy according to Pristin and Michael (2014) applies not only to the students but also to the teachers and the schools. A school therefore should put the confidence in their students that they can make it when they are there and also that they have the best teachers. Similarly, Christopher (2012) study in USA revealed that, High specific self - efficacy in individuals is less likely cheat. But both levels general self-efficacy (G.S.E) and specific self-efficacy (SSE) predict lower rates of cheating overall. Christopher (2012), finally confirms that self-efficacy reflects the belief that a person is able to successfully perform a task, even though he noted that self-efficacy beliefs are not necessarily accurate as an individual's confidence in being able to perform effectively does not mean that the individual is actually able to do so.

"Students will always cheat because examination is difficult and the pass mark is high. Those who understand the subject or question are used to assist those who don't understand. This is cheating by both, the ones assisted and the ones assisting."(Student 2)

The views of Student 2 shows that those involved in cheating are not only those with low selfefficacy but also those with high self-efficacy. Those with low self-efficacy influence those with high efficacy to give them assistance; hence both are involved in cheating.

Those students with better knowledge of the questions will always find a better way of passing the answers to those who don't, while those who don't know device a better method of receiving the past answers. (Student. 5)

The statement by Student 5 indicates that cheating has been perceived as a tool by low selfefficacious students to pass exams and not highly efficacious ones. The findings are in tandem with a study by McCabe et.al,(2012) in USA, who revealed that students cheat because of the influence of friends and lack of self-efficacy. Afokasade (2014) also carried out a study in Lagos, Nigeria and found out that: - students with low or high self-efficacy get involved in cheating while taking advantage of laxity in supervision and invigilation. Barzegar and Khezri (2013) also confirmed that 
self-efficacy is a factor within schools which influence cheating among students and made a comparison and a contrast between the self-efficacy in both male and female genders. This study was also given supported by, a study in Ethiopia by Utti, A (2012), who revealed that parental involvement had a high influence on students' self-efficacy. According to Uti (2012), self-efficacy is a product of parental involvement which can determine a student's attitude towards examination cheating. Another respondent also reported;

\begin{abstract}
Cheating is not good and us the ministry agents discourage it at all costs. The only worry we have is that those who cheat are smarter than us and use very complicated means that we can't easily get. We have always sounded alarm that those caught cheating would face dire consequences but this has never stopped, those who cheat are jut clever people or students.(County Education Officer. 1)
\end{abstract}

The Education officer 1 expression is an indicator that examination cheating is mainly done by more efficacious students than the rest. The officer points out the I.Q of the examination cheating and conceals that they can't match than this statement is given support by Ong'ong'a and Akaranga (2013) which revealed that those student involved in cheating use very well prepared notes which fit well with the questions given. They also use accurate methods that even the supervisors and invigilators cannot match. This shows that there is a significant relationship between self-efficacy as a school factor and examination cheating among students. The findings echoed studies such as Stumber (2009) and Mularidharan and Venkatesh (2009) who came up with several candid studies on examination cheating. Stumber (2009) observed that cheating is mainly personal though can be influenced by peers.

The qualitative findings during in-depth interviews also revealed that self esteem is a factor to consider when addressing examination cheating tendencies. One of the students indicated that:

Students cheat so much, because they feel that what comes from "outside" is the right thing to be done and also because they are not confident with what they have they can't stand on their own they have low self esteem (Teacher I).

The respondent, Teacher 1 is a teacher who feels that a student will only cheat when they have no confidence in what they have or know. A student who has confidence in the knowledge they posses will always be ready to do exams without cheating. In self esteem the learner is expected to take the task without promoting and this one applies even to examinations (McCabe, Trevino (2012). The verbatim expressions from the interviews by respondents therefore showed that External locus of control as a personal determinant of examination cheating was a key determinant of examination cheating as follows:

I can't stop cheating as long as my friends or others cheat; I cheat because they encourage me to do so, since those who cheat are the ones who get better courses. My colleagues who have cheated in exams have always got better performance; therefore they encourage me to do so. (Student 1)

The views of Student 1 are an indicator that cheating among students is mainly influenced by others and mainly their friends. The External locus of control is an external pressure that compels the student to cheat in examinations. External locus of control presented itself clearly with a significant number of respondents supporting it which is quite significant.

"I always want to be independent but my friends always follow me to make me do their will they involve me in their actions and hence I cheat in exams because of them." (Student 1)

The Student 1 further narrated his feelings about the information of friends. The respondent could not manage himself or herself hence his actions were determined by friends which means that the individuals may want to be independent especially in doing examinations but they are forced to cheat having been influenced by their peers. (Paul, Grimes, and Jan, 2006) while McCabe and Trevino, (2012) a firmed that students cheat because they lack principles and are unable to think independently. 
I cheat because; there is no any other better way of passing exams. I have to be sure that I have given the correct answer to any questions. Most of the answers are from the examiners or marking scheme so are more accurate, to use that using my own brain (Student 2)

The response is from student 2 who feels that what is prepared prior to examination is always accurate and should be used if one wants to be sure of passing. The expression by the above respondent is an indicator that the above student cannot tackle any examination with confidence unless he/she receives an external support this is an indication of low self efficacy or lack of self efficacy. This was also supported by Finn and Michael, (2014) who found out that cheating is more likely among lower achieving students when they do not identify with school than among higher achieving students with low level of academic achievement. This was confirmed that adherence to teachers' instructions and behaviour has a direct bearing to students' behaviour towards cheating in examinations in schools.

We cheat because our friends also cheat and encourage us to do so. When they succeed in cheating they roll down the syndrome to us citing the benefits there in.' as long as our friends cheat and successfully overcome the challenges, I also must cheat and succeed like them so as to narrow their chances of occupying my chance (Student 4).

The response from student 4 indicates that students have the influence of their fellow students within the schools that encourage them to cheat. However much the teachers or examination council may try to eradicate the act by imposing severe legislation on the offenders, the syndrome may end because it is the external pressure among students who influence the act.

\footnotetext{
Students cheat much when influenced by fellow students or peers than when influenced by teachers, parents or principals. The teachers will always want their students to pass exams out of sheer hard work from both the student and the teacher though they are often overcome by circumstances that prevail.(Head teacher 2).
}

The respondent, Head teacher 2 is a principal of one of the schools under study and affirms that external pressure is so strong that it has a direct bearing on the behaviour of individuals and that's why it can influence examination cheating among the students in secondary schools. Youths can be prompted by their peers to behave in a manner that does not show independent thinking and this may also prompt the act of self deception or even cheating (McCabe, Trevino \& Butterfield, 2012). External locus of control is a factor among the youths that accounts for their un-ethical behaviours presenting vividly in examination cheating, (Ong'ong'a \&Akaranga, 2013).

\section{Conclusion and Recommendation}

The Personal determinants of examination cheating tendencies were observed as self efficacy, External locus of control, Low Self esteem and gender factor among students. It emerged prominently that most of the students cheat due to low self efficacy and External locus of control according the data collected from the respondents. The study finally concluded that examination cheating is more prominent in less efficacious students than in more efficacious ones and that selfefficacy is a factor that can't be avoided as determinant of examination cheating tendencies among secondary school students. External locus of control was revealed as the external influences that lead to examination cheating. It was also established that there was significant relationship between self esteem, self confidence and examination cheating. This was more attributed to those with low self esteem and low self confidence than those with high self esteem and self confidence. The Ministry of Education to establish or initiate an aspect of Moral and Ethical behaviour Development in schools to enhance teacher and student commitment to examination ethics since the study revealed that there is significant relationship between teachers and examination cheating. 


\section{References}

Afokasade, A. \& Suleiman (2014) Determinants of Nigerian students. Disposition to cheating. The Perpetrators' perspective. The international Journal of Learning in Higher Education, Vol 20 issue 4, 2014, PP31 - 37.

Andrabi, T (2006) Public -Private Debates in Education: whether Private without Integrity: Journal of Academic Prevalence, 81(3):718-726.2006.

Anderman, E M., \& Murdock, T. B. (2007). Psychology of Academic Cheating. London: Elsevier Academic Press.

Axtman, K. (2005). When test' cheaters are the teachers. The Christian Science, January 11 Available at: 11. www.csmonitor.com/ Monitor 2005/0111/p01s03-ussc.html.

Bandura, A. (1986). Self-efficacy: The exercise of control. New York: W.H. Freeman.

Beuchamp A \& Murdode; T (2009) Cheating 25, June 2013. http.//www.education.com/reference/articles.

Bisong, NN (2009). Cheating tendencies in Examination among secondary schools in

Nigeria: A case study of schools in the Odulepani local Government Area. Journals. Sage pub.com/da/abs/10.2304/pf/c.2009.7.4.410.

Brett, Ekant, \& Pervant (2007). Self Referencing and consumer Evaluations of Larger - sized female models: A weight locus of control perspective. Marking Journal 18(3): 197 - 209.

Cizek.G.I (2003), Detecting and preventing classroom cheating: Promoting integrity in assessment. California: Corwin.

Cizek, G. I. (1999) Cheating on tests: How to do it, detect it and prevent it. New Jersey: Lawrence Erlbaum Associates.

Chaudhury, Nazmul, Jeffrey Hammer, Michael Kremer, Karthik Muralidharan, and F. Halsey Rogers. (2006). "Missing in Action: Teacher and Health WorkerAbsence in Developing Countries." Journal of Economic Perspectives. 20(1): 91-116.

Chinamasa, E. Mavaru, L, Maphosa, C \& Tarambawamwe, P. (2011). Examination cheating. Exploring strategies and contributing factors in five universities in Zimbabwe. Journal of innovative research in Education 1 (1): P.P 86-101).

Christine H.L Graven J, Gary M.R, Davis, D, Murray, M.A \& Rydall A.C (2015): empirical study on relationship between self efficacy and adherence Department of psychology, college wing 2. 306, Toronto University, press, Toronto, Ontario (Canada).

Christopher, A.W (2012). The roles of self efficacy and self deception in cheating on unprotected internet Testing in Mankato. Minaseta state University. (Mankato).

Chudzika \& Czupala (2014) Psychological and moral determinants in accepting cheating in Poland. .www.p.Jap.psychologia.uni.wroc.pi-/..../Poland.Europe .institute of psychology, university of sitesia, grasynkiego. 53, 40-126 Katowixer

Cohen, L, Manion. L, Morrison. K, (2007) Research Methods in Education: London: Rout Ledge Falmer.

Cresswell, J.W, (2014) Research Design: Qualitative; Quantitative and Mixed method approaches Thousand Oaks, C.A Sage.

Davis, F.S Drinan, F.P \& Gallant, B.T (2012) Cheating in school. What we know and what we can do. Willey Blackwell. John Willey LLtd.

Dickie, M. (2006). Experimenting: Does it increase learning in introductory Microeconomics? Journal of Economic Education 37 (Summer): 267-88.

Erondu A,Shariland \& Okpala A (2006). Towards Effective Teaching of Music in Nigerian schools. International Journal of Research in Education 3(1) 1577-163.

Fasasi, Y.A. (2006). "Quality Assurance: A Practical Solution to Examination. Vol. 2 No. 8. pp 22-39.

Finn, K. V., \& Frone, M. R. (2004). Academic performance and cheating: Moderating role of school identification and self-efficacy. Journal of Educational Research.97(3), 115-122.

Gideon, P. \& Bruin (2007) Examining the cheats: The role of consciousness and excitement seeking in academic dishonesty. Department of Human Resource Management, University of Johannesburg; Aukland Park. South Africa.

Kisamore, J, Stone T \& Jahawar, I (2007) Academic integrity. The relationship between individual and situational factors on misconduct contemplations Journal of Business Ethics, 75, (381-394).

Lambert, B., and Foss, K (2005). Guiding students from cheating and plagiarism to Honesty and integrity: Strategies for change. Engle Leland, B. (2002). Plagiarism and the Web. Macomn, IL: Western Illinois University. Available at: http: // www.wiu.edu/users/mfbh/wiu/plagiarism.htm

Marian \& Webster (2010).Malpractices in examinations of Nigerian Secondary Schools: International Journal of Africa and African American Studies, Vol. V,No. 2 July (2139-217)

Matamande; Mandimika. W, Tenderera. E \& Nyikahadzoi, 2 (2010) Exploring management strategies to reduce cheating in written exams. A case study of Midland State University, Zimbabwe. 
McCabe. D.L, Trevino. L.K. \& Butterfield, K.D (2012) Cheating in college: why students do it and what educators can do about it. John Hopkins University Press. The United States of America.

McCabe, D.L (2006), Cheating among college and university students: A North American perspective International Journal for Education Integrity. Vol 1 No. 1 (2006).PP2009-2018

Mizala\& Schneider (2013). Academic misconducts and malpractices in examinations: Journal of College Student Development. 98(3) 117-128.

MOEST, (2014). Use of mobile phones during examinations. MOE/CON/FIII/41/5.Nairobi: MOE

Muralidharan, Karthik, and Sundaraman, V (2008). "Contract Teachers: Experimental Evidence from India." http://econ.ucsd.edu/-kamurali/contract\%20teachers.pdf

Ogodulunwa, CA (2011). The attitude of students to cheating in Examination in Nigeria. Journal of Education. Volume 10, number 7, PP 384-398.

Ong'ong'a, J. J. \&, Akaranga, S.I (2013) The Phenomenon of examination Malpractice: An example of Nairobi and Kenyatta Universities. Journal of Education and Practice Vol. 4.19: pp 1 - 40.

Parameswaran, A. (2007) Student dishonesty and faculty responsibility,Journal of Teaching in Higher Education12, 263-274.

Passow, H.J., Mayhew, M. J., Finelli, C.J., Harding, T.S \& Carpenter, D.D (2006) Factors influencing engineering students' decisions to cheat by type of Assessment: Research journal in Higher Education 47, 643-684.

Paul, W. Grimes \&. Rezele ,P. (2006) The determinants of cheating by High school students: A comparative study of Academic Dishonesty in the Transitional Economies. International Review of Economic of Education, Vol 4 issue 2 P.P 23-45.

Punch. K. (2005). Introduction to Social Research: Qualitative and Quantitative approaches. London Sage.

Raburu, P.A (2011). Women Academics Careers in Kenya. PhD Thesis. Lancaster University-UK.

Raburu, P.A (2015). Motivation of women academics and balancing family and Career. Journal of Educational and Research Vol.5. NO.1:359-370.

Republic of Kenya (2010) Education statistics and indicators fact sheet. Nairobi; Ministry of Education

Republic of Kenya (2008). The 2008 KCSE Results Analysis, Nyanza Province, Kisumu: Unpublished Result Analysis.

Sonja \& Panu (2012). Academic Misconduct in higher education: Durham University Press. Durham E Thesis.online.http://ethesis.dur.ac.uk/2546/.

Uti, A (2012) Relationship between parenting styles and students academic achievement in secondary schools in Ethiopia.Journal of Education and Research vol.4 pp 243-271. 